\title{
Not yet, but eventually
}

\section{MAX WYSS}

Unfortunately, it is typical for debates about earthquake prediction research to be based in part on incorrect assertions $\frac{1,2}{2}$. The first two sentences in the moderator's introduction follow this tradition. Contrary to his suggestion, the recent earthquake in Colombia has done nothing to show the inability or ability of science to predict earthquakes, because this problem simply has not been studied in Colombia.

\section{Significant global effort?}

Also, to say that a "significant global effort [...] has gone into the investigation of the nucleation process of earthquakes" does not present the correct picture. When the USA or Great Britain seriously mean to solve a problem, they put several orders of magnitude more resources into it, as they have done during the past few decades in detecting underground nuclear explosions and discriminating between them and natural seismic phenomena. The massive effort of rigorous science that is actually needed if we want to understand the nucleation process of earthquakes is not made in any country.

\section{Do all earthquakes strike suddenly?}

The next statement in the introduction, that "earthquakes [...] appear to strike suddenly," is a phrase used by people who wish to argue that earthquake prediction is impossible, however, it does not reflect the facts correctly. We should not argue about the facts in scientific discussions. Yet the small group of scientists who argue that earthquake prediction is impossible $\frac{1.2}{}$, as well as those advocating the view that the problem of earthquake prediction is already solved ${ }^{3}$, often distort the facts.

The fact is that many main shocks do not occur "suddenly": $10-30 \%$ of them are preceded by foreshocks during the week before their occurrence ${ }^{4-8}$; some are preceded by year-long pre-activity 9 ; some are preceded by increased moment release during the years before them $\frac{10-14}{}$, and some are preceded by seismic quiescence $\frac{15-17}{}$. On the basis of these seismicity patterns, some earthquakes have been predicted correctly $\frac{18-24}{}$ and one case has been predicted, but with incorrect parameters $25-27$.

\section{What is a successful prediction?}

By defining a useful earthquake prediction as one based on which "a planned evacuation can take place", the moderator sets up the rejection of the idea that earthquake prediction should be studied, because it allows him to make the misleading statement that "few seismologists would argue that deterministic prediction as defined above [my italics] is a reasonable goal". The wellknown element of randomness in the initiation of a large rupture $\underline{28}$, which comes into play at the very end of an energy loading cycle, foils the use of short prediction windows in most cases. Nevertheless, many benefits derive from predictions that have time windows of up to several years. These have been spelled out repeatedly. Hence, most seismologists would agree that any well-formulated and well-founded prediction is useful.

\section{Advances of science might be unexpected}

When the "standard practice" of "time-independent hazard" estimates is held up in the introduction as solid, well-established science, this is in the mainstream of engineering seismological opinion, but some serious 
shortcomings of this method have recently been documented. The existence of precariously balanced rocks near active faults in the Western USA ${ }^{29-32}$ shows clearly that accelerations calculated by the "standard practice" are overestimated in many locations.

Also, we are developing evidence that asperities are the only parts of faults containing information about the frequency of main shocks, and that a new method of estimating local recurrence time might correct the flawed estimates by the "standard practice," which relies in part on information from creeping

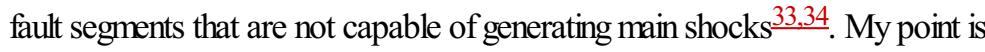
that, regardless of how well accepted or attacked some research fields and methods are, curious human beings will always investigate further and eventually come up with advances of our knowledge, including unexpected rejection of standard practice, and will arrive at solutions to problems hitherto thought by some to be unsolvable.

\section{Main problems plaguing prediction research}

The problems plaguing earthquake prediction research on which we should focus, in my opinion, are (a) the improvement, or elimination from journals, of scientifically weak work $\frac{35-37}{}$, and (b) the exposure of work that contains errors $\frac{38,39}{}$ and statements made by scientifically unqualified publicity seekers. Unfortunately, human psychology is such that hasty workers and true believers will always mess around with the problem of earthquake prediction that fascinates them. Therefore, we must learn how to conduct rigorous, quantitative prediction research in spite of the distractions generated by unqualified people.

We have not yet arrived at this point. Currently, funding for earthquake prediction research in most Western countries is puny because it is considered a 'hot potato' by most funding agencies and many peer reviewers.

\section{The future of earthquake prediction research}

So, what about the future of studying the earthquake failure process applied to possible prediction? I am pessimistic about the near future and optimistic about the long term. It seems that we are destined to hear more invalid statements in the debate about the value of earthquake prediction research. However, there can be no doubt that a preparatory process to earthquake rupture exists (foreshocks demonstrate this), and I am confident that ingenious and resilient people, who will come after us and will be amused by this tempest in a teapot about the prediction of earthquakes, will eventually improve our ability to predict some earthquakes in favourable areas, although not often with time windows as short as demanded by the moderator.

\section{Max Wyss}

Geophysical Institute, University of Alaska, Fairbanks, Alaska, USA

\section{References}

1. Geller, R.J., Jackson, D.D., Kagan, Y.Y. \& Mulargia, F. Earthquakes cannot be predicted. Science 275, 1616-1617 (1997).

2. Wyss, M. Cannot earthquakes be predicted? Science 278, 487-488 (1997).

3. Varotsos, P., Eftaxias, K., Vallianatos, F. \& Lazaridou, T. Basic principles for evaluating an earthquake prediction method. Geophys. Res. Lett. 23, 1295-1298 (1996).

4. Jones, L.M. Foreshocks (1966-1980) in the San Andreas system, California. Bull. Seism. Soc. Am. 74, 1361-1380 (1984).

5. Shibazaki, B. \& Matsu'ura, M. Foreshocks and pre-events associated with the nucleation of large earthquakes. Geophys. Res. Lett. 22, 1305-1308 (1995).

6. Console, R. \& Murru, M. Probability gain due to foreshocks following quiescence tested by synthetic catalogs. Bull. Seism. Soc. Am. 86, 911-913 (1996).

7. Maeda, K. The use of foreshocks in probabilistic prediction along the 
Japan and Kuril Trenches. Bull. Seism. Soc. Am. 86, 242-254 (1996).

8. Ogata, Y., Utsu, T. \& Katsura, K. Statistical discrimination of foreshocks from other earthquake clusters. Geophys. J. Int. 127, 1730 (1996).

9. Bowman, J.R. A seismic precursor to a sequence of Ms 6.3-6.7 midplate earthquakes in Australia. Pure Appl. Geophys 149, 61-78 (1997).

10. Varnes, D.J. Predicting earthquakes by analyzing accelerating precursory seismic activity. Pure Appl. Geophys 130, 661-686 (1989).

11. Bufe, C.G., Nishenko, S.P. \& Varnes, D.J. Seismicity trends and potential for large earthquakes in the Alaska-Aleutian region. Pure Appl. Geophys 142, 83-99 (1994).

12. Bufe, C.G. \& Varnes, D.J. Time-to-failure in the Alaska-Aleutian region: an update. Eos 77, F456 (1996).

13. Sykes, L.R. \& Jaume, S.C. Seismic activity on neighboring faults as a long-term precursor to large earthquakes in the San Francisco Bay area. Nature 348, 595-599 (1990).

14. Bowman, D.D., Ouillon, G., Sammis, C.G., Sornette, A. \& Sornette, D. An observational test of the critical earthquake concept. $J$. Geophys. Res. 103, 24359-24372 (1998).

15. Wiemer, S. \& Wyss, M. Seismic quiescence before the Landers $(M=7.5)$ and Big Bear $(M=6.5) 1992$ earthquakes. Bull. Seism. Soc. Am. 84, 900-916 (1994).

16. Wyss, M., Shimazaki, K. \& Urabe, T. Quantitative mapping of a precursory quiescence to the Izu-Oshima 1990 (M6.5) earthquake, Japan. Geophys. J. Int. 127, 735-743 (1996).

17. Wyss, M. \& Martyrosian, A.H. Seismic quiescence before the M7, 1988, Spitak earthquake, Armenia. Geophys. J. Int. 134, 329-340 (1998).

18. Dieterich, J.H. et al. Probabilities of Large Earthquakes in the San Francisco Bay Region, California (U. S. Geol. Surv. Circular 1053, Washington, DC, 1990).

19. Sykes, L.R. \& Nishenko, S.P. Probabilities of occurrence of large plate rupturing earthquakes for the San Andreas, San Jacinto, and Imperial faults, California. J. Geophys. Res. 89, 5905-5927 (1984).

20. Scholz, C.H. The Black Mountain asperity: seismic hazard of the southern San Francisco peninsula, California. Geophys. Res. Lett. 12, 717-719 (1985).

21. Nishenko, S.P. et al. 1996 Delarof Islands earthquake-a successful earthquake forecast/prediction? Eos 77, F456 (1996).

22. Wyss, M. \& Burford, R.O. Current episodes of seismic quiescence along the San Andreas Fault between San Juan Bautista and Stone Canyon, California: Possible precursors to local moderate main shocks. U.S. Geol. Survey Open-File Rep. 85-754, 367-426 (1985).

23. Wyss, M. \& Burford, R.O. A predicted earthquake on the San Andreas fault, California. Nature 329, 323-325 (1987).

24. Kossobokov, V.G., Healy, J.H. \& Dewey, J.W. Testing an earthquake prediction algorithm. Pure Appl. Geophys 149, 219-248 (1997).

25. Kisslinger, C. An experiment in earthquake prediction and the 7 May 1986 Andreanof Islands earthquake. Bull. Seism. Soc. Am. 78, 218229 (1988).

26. Kisslinger, C., McDonald, C. \& Bowman, J.R. in IASPEI, 23rd General Assembly (Tokyo, Japan) 32 (1985).

27. Kisslinger, C. in Meeting of the National Earthquake Prediction Evaluation Council (Anchorage, Alaska) 119-134 (U.S. Geol. Surv. Open-file Rep. 86-92, 1986).

28. Brune, J.N. Implications of earthquake triggering and rupture propagation for earthquake prediction based on premonitory phenomena. J. Geophys. Res. 84, 2195-2198 (1979).

29. Brune, J.N. Precariously balanced rocks and ground-motion maps for Southern California. Bull. Seism. Soc. Am. 86, 43-54 (1996).

30. Bell J.W., Brune, J.N., Liu, T., Zreda, M. \& Yount, J.C. Dating precariously balanced rocks in seismically active parts of California and Nevada. Geology 26, 495-498 (1998). 
31. Brune, J.N., Precarious rocks along the Mojave section of the San Andreas fault, California: constraints on ground motion from great earthquakes. Seism. Res. Letts 70, 29-33 (1999).

32. Brune, J.N., Bell, J.W. \& Anooshehpoor, A. Precariously balanced rocks and seismic risk. Endeavour N.S. 20, 168-172 (1996).

33. Wiemer, S. \& Wyss, M. Mapping the frequency-magnitude distribution in asperities: An improved technique to calculate recurrence times? $J$. Geophys. Res. 102, 15115-15128 (1997).

34. Wyss, M. \& Wiemer, S. Local recurrence time in seismically active areas may be the most important estimate of seismic hazard. Eos 79, F644 (1998).

35. Wyss, M. Evaluation of proposed earthquake precursors (American Geophysical Union, Washington, DC, 1991).

36. Wyss, M. Second round of evaluations of proposed earthquake precursors. Pure Appl. Geophys 149, 3-16 (1997).

37. Wyss, M. \& Booth, D.C. The IASPEI procedure for the evaluation of earthquake precursors. Geophys. J. Int. 131, 423-424 (1997).

38. Geller, R.J. Debate on evaluation of the VAN method: Editor's introduction. Geophys. Res. Lett. 23, 1291-1294 (1996).

39. Geller, R.J. in A Critical Review of Van (Lighthill, J.H. ed.) 155-238 (World Scientific, London, 1996). 